\title{
AGERATINA ADENOPHORA (ASTERACEAE) NEW SPECIES TO THE ITALIAN ALIEN FLORA AND OBSERVATIONS ON ITS ENVIRONMENTAL THREATS
}

\author{
Emanuele DEL GUACCHIO ${ }^{1}$
}

\begin{abstract}
Ageratina adenophora is recorded for the first time in Italy (Campania region). Its naturalization status and ecology are discussed, also providing a morphological comparison with the related taxa (both occurring in Italy) A. ligustrina and Eupatorium cannabinum. Some remarks on potential threats for habitat and native flora are provided as well.
\end{abstract}

Key words: Ageratina Spach, Alien flora, Ecological impact, Eupatorieae Cass., Italy.

Izvleček

Pojavljanje vrste Ageratina adenophora smo zabeležili prvič v Italiji (regija Campania). Obravnavamo njen status naturalizacije in ekologijo, obenem pa podajamo tudi morfološko primerjavo s sorodnima vrstama A. ligustrina in Eupatorium cannabinum, ki se pojavljata v Italiji. Dodatno smo izpostavili potencialno ogroženost habitatov in avtohtone flore.

Ključne besede: Ageratina Spach, tujerodna flora, ekološki učinek, Eupatorieae Cass., Italija.

\section{INTRODUCTION}

Discovery of new aliens and evaluation of their naturalization status are crucial for their correct management. For Italy, a comprehensive work was recently published by Celesti-Grapow et al. (2010). In spite of this, the number of exotic species is in steady increase (e.g. Alberti 2012, Galasso 2012, Stinca et al. 2012, Villa et al. 2012) and in some cases they are recognized as invasive (e.g. Iamonico 2011; Iberite et al. 2011).

During the botanical investigations on the flora of Southern Italy, two separate populations referred the genus Ageratina Spach were found in Campania region. The genus is rarely recognized in Italian floras, being included in Eupatorium L. (e.g. Pignatti 1982). However, several Ageratina species are considered aliens out of their native area (Americas) (Nesom 2006) and some are invasive in several countries (e. g. Wang \& Wang 2006).

With the aim to correctly identify the Ageratina populations found, a morphological study is car- ried out, also in comparison with related species $A$. ligustrina (DC.) R. M. King \& H. Rob. and Eupatorium cannabinum L. Moreover, taxonomical, ecological notes and naturalization status are provided.

\section{MATERIALS AND METHODS}

The collected specimens are kept in NAP (abbreviations according to Thiers 2011) and in the personal Herbarium of the author (Herb. Del Guacchio). For comparison purpose, exsiccata from Mexico, Algeria, Madeira and Canarias were also examined (FI and NAP, sub E. adenophorum and E. glandulosum) plus images available on the web (SEINet 2012, PlantNET 2012). The following characters were analyzed: habitus (herbaceous or suffruticose), shape of the leaf blades, leaf margins, presence of capitate-trichomes and stipitate glands on peduncles, shape of the cypselae, shape of the anthers, presence of glands on the corolla lobes, shape of the fruits.

\footnotetext{
${ }^{1}$ Bagnolifutura SpA, via Diocleziano 341-343, 80124-Naples, e-mail: emanuele.delguacchio@email.it
} 


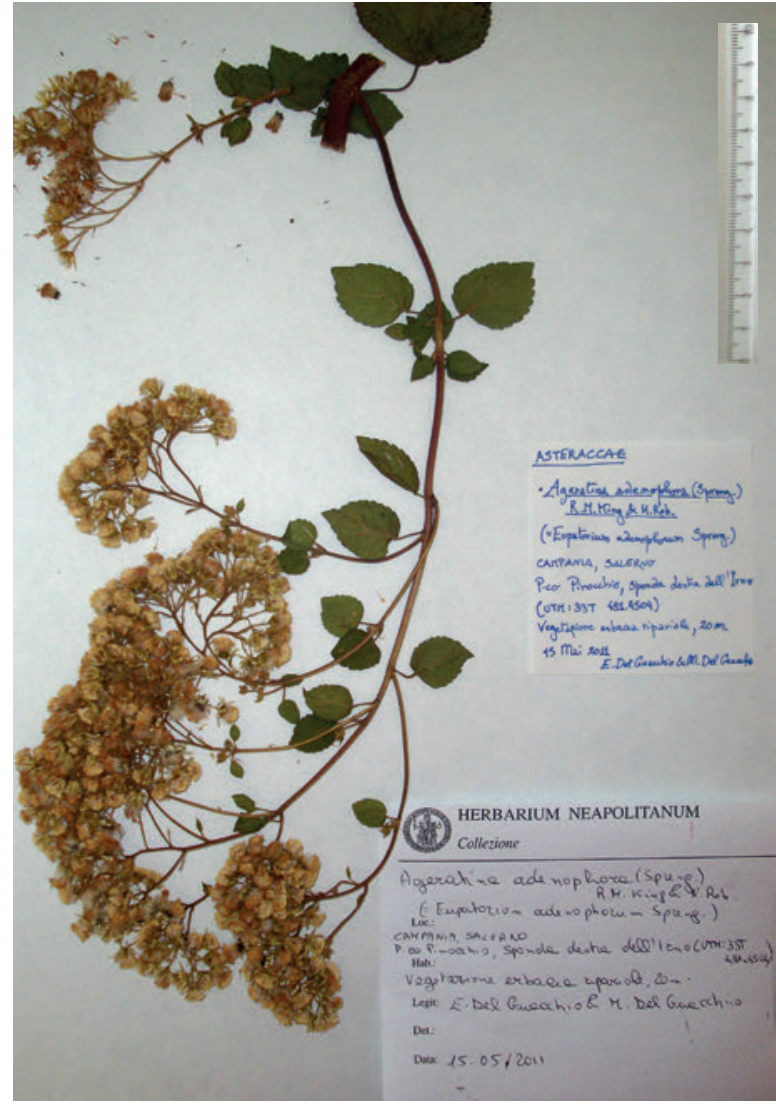

Figure 1: Ageratina adenophora from Salerno (Herb. Del Guacchio).

Slika 1: Ageratina adenophora najdena v Salernu (Herbarij Del Guacchio).

The specimens were identified by the keys in Nesom (2006). The original descriptions by Sprengel (1826) and Kunth (Bonpland et al. 1818) were also examined.

The plants from Campania (photos!) were also examined by J. Pruski (Missouri Botanical Garden) in order to confirm the identification.

Literature was extensively examined to detect previous indications of the species in Italy and in Campania (e.g. Caputo et al. 1994, CelestiGrapow et al. 2010, Conti et al. 2005, Greuter 2006-2009, Lacaita 1921, Pignatti 1982).

The populations were observed in the field respectively for 7 years (Sorrento) and 5 years (Salerno). In order to evaluate adaptability and drought resistance, vegetative fragments from both populations were collected and cultivated at $100 \mathrm{~m}$ s.l.m. (locality Quercioni of Altavilla Silentina, Salerno province, Campania region), on clayey substrate.

The evaluation of the naturalization status follows Pyšek et al. (2004).

\section{RESULTS AND DISGUSSION}

Genus Ageratina was first described by Spach (1841) and distinguished from related taxa included in tribe Eupatorieae Cass. (e.g. Stevia, Ageratum, Coelestina, Eupatorium, Ayapana, Mikania, Liatris, Suprago), but on the basis of rather obscure diagnostic features (King \& Robinson 1970). These latter authors highlighted important diagnostic features of florets and fruits, circumscribing genus Ageratina in a modern way. Their treatment (including cytological data) was later accepted in the comprehensive work for the tribe (King \& Robinson 1987) and it has been supported by molecular data (Robinson et al. 2009). As a conseguence, Ageratina is definitively worth of distinct generic rank, and now it is included in the subtribe Oxylobinae R. M. King \& H. Rob. (King \& Robinson, 1978).

A. adenophora is based on Eupatorium adenophorum Spreng. (Sprengel 1826), who cited it as synonym of E. glandulosum Kunth (Bonpland et al. 1818). This latter name is illegitimate under art. 53.3 of the ICNB (McNeill et al. 2012) being a later homonym of E. glandulosum Michx. (Michaux 1803).

The genus includes about 265 species from tropics and subtropics of the Americas (Chen et al. 2011). In Europe, 3 species are recognized (Greuter 2006-2009), although in Flora Europaea (Tutin 1976) Ageratina is included in Eupatorium, and only one species attributable to the genus is recorded (E. adenophorum). In Italy, $A$. adenophora is not reported by Pignatti (1982) who indicates it (sub E. adenophorum) only in Corsica (included in the coverage by Pignatti, although French territory). Recently, Celesti-Grapow et al. (2010) report A. ligustrina (DC.) R. M. King \& H. Rob. (E Eupatorium ligustrinum DC.) as a casual alien for Liguria (northern Italy).

$A$. adenophora, native of Mexico, is widely naturalized in the world: Northern America, Europe, Africa and Macaronesia (Canary Island, Madeira, Azores archipelago), temperate and tropical Asia, Australia, New Zealand and Pacific Islands (USDA 2012). In Europe it is reported as naturalized in Portugal, Spain, Corse and Kriti and as a casual alien in France and Germany. Its status is not clear for Croatia and continental Greece. Finally it is also recorded for Algeria and Lebanon (Greuter 2006-2009).

The plants observed perfectly match with the original description and the exsiccata analyzed. 
J. Pruski also confirms the identification. According to all the examined literature, the species is new to the flora of Italy.

In both the discovered localities (see Table 1), A. adenophora appears as a well established xenophyte. It has been observed for several years and, also on account of its developed habitus (shrub), it cannot be considered an ephemeral plant. (Pysek et al. 2004).

A. adenophora is rarely cultivated as ornamental in Campania, for example at Botanical Garden of Naples (Tenore 1845, sub Eupatorium adenophorum) and probably the naturalized plants originate from cultivated stocks. However, no evidence of cultivation was found by field observations in the surroundings of the observed localities.

Cultivation tests showed a rapid growth of the plants both using vegetative parts (especially by rootstock fragments), and seeds (by pappus-furnished cypselae) both in pots and in soil. Several seeds are proved to be of asexual origin and partially non-viable (Parsons 1992). It is not possible, therefore, to establish the origin (sexual or vegetative) of the two populations. The population on rocks in Sorrento might have originated by wind dispersion of seed, that of Salerno might have originated via water seed dispersal or vegetative fragments.

In cultivation, the plants can endure short periods of cold (at least immediately above freezing temperature by night), but colonization of mountain localities is hard to envisage.

The clones cultivated near Salerno show considerable drought resistance, up to three weeks. Even if the aerial parts mainly dried, when watered the plants readily produced young shoots from the base of the stem or the rootstocks.
However, after one week in drought condition, the plants clearly suffer, while longer periods of drought is fatal. This proves that in local climate Ageratina is strictly linked to wet environments and cannot colonize dry open habitat. Even if it cannot be reported as invasive species in Italy at the present state of knowledge, it is potentially threatening as it may colonize natural and seminatural habitats. Experiments by Hong-bang et al. (2007) showed the great ecological plasticity of this species and its biological strategy (also involving allelopathy) in invading new ecosystems. A. adenophora already revealed as a noxious invasive in Chinese forests (Hong-bang et al. 2007), Australia (Parsons 1992), South Africa (Kluge 1991, Heystek et al. 2011), Hawaii Islands (Barreto \& Evans 1988, PIER 2011) and California (Fuller 1981): it is named "banmara" (i.e., "killer of the forests") in Nepal (Sharma \& Chhetri 1977). Its worst threat potential is the competition with the native species, the alteration of soil chemistry, the soil depletion, and the toxicity for cattle (Parsons 1992, Chen et al. 2011).

In particular, in Campania it may compete against native species both in stillicidious rocky coasts and along rivers in warm climate. In Sorrento several endemic entities were observed to grow together with Ageratina. Several other invasive species colonize the preferred habitat of $A$. adenophora [e. g. Ipomoea indica (Burm.) Merr., Carpobrotus acinaciforme (L.) N. E. Br.], replacing autochthonous species (pers. obs.). These species are able to compete against endemic plants which usually disappear in sites where the ecological conditions are less prohibitive for alien competitors. In the studied localities, already

Table 1: Data of observed site and populations of A. adenophora (note that probably they are clones started by two founders).

Tabela 1: Podatki o proučevanih rastiščih in populacijah vrste A. adenophora (verjetno gre za klone, ki so nastali iz dveh osebkov).

\begin{tabular}{lll}
\hline & Sorrento & Salerno \\
\hline Locality & Between Marina Piccola and the public & Parco Pinocchio, along the right ripe of \\
& garden, next to the stairway & Irno river \\
UTM geographic coordinates & $33 T$ T97.449 & $33 \mathrm{~T} 481.450$ \\
Altitude (m a.s.1.) & 30 & 20 \\
Habitat & Wet rocky coast & River banks \\
Exposition & North-East & East \\
Pedology & Grey tuff rubble & Alluvial deposits (clay and sands) \\
Vegetation & Sparse vegetation with mixed rocky & High-herbaceous riparian vegetation \\
& and synanthropic species & \\
Population area $\left(\mathrm{m}^{2}\right)$ & About 2 & About 20 \\
Height of plants $(\mathrm{m})$ & $0.8-1.2$ & About 2.5 \\
\hline
\end{tabular}


colonized by synanthropic and subcosmopolitan species, Helichrysum litoreum Guss. (endemic of the southern Tyrrhenian coasts), Seseli polyphyllum Ten. (limited to few locations in Latium and Campania, central-southern Italy), Limonium cumanum (Ten.) Kuntze (exclusive of the Sorrento peninsula, neighboring islands and Naples) and Centaurea tenorei Lacaita (restricted to the Sorrento peninsula) were observed. In particular, $A$. adenophora overpowers the heads of $H$. litoreum and $C$. tenorei growing in the same locations and depriving them of space and light.

The flora in the locality in Salerno is surely less valuable than that of Sorrento and there A. adenophora only competes with Arundo donax L., a well known invasive archeophyte from China. Several other noxious invasive aliens can be observed as well, such as Bidens frondosus L., Helianthus tuberosus L., Paspalum distichum L., together with native shrubs (e.g., Salix alba L.) and herbs [e.g, Cynodon dactyolon (L.) Pers., Persicaria maculosa S. F. Gray, Alisma plantago-aquatica L.]. Nevertheless, the hazard even appears more serious. In fact, in this habitat this species can spread very quickly, colonizing new territories and seriously altering them (Wang \& Wang 2006). It is important to note that about the $30 \%$ of the species not recently found of Campania and many of the more rare or endangered are limited to wet lowlands. In any case, wet lowlands, together with sandy coasts, represent the most threatened and altered ecosystems in the region (pers. obs.)

Unfortunately, Italian legislation is still very defective in the control of the so-called "green pollution" (Brundu, 2008), even if impact of alien species on human health, economic activities and habitat conservation is serious, or disastrous in some cases (Andaloro et al. 2009, Celesti-Grapow et al. 2010). Several methods of management were suggested in the countries where $A$. adenophora became invasive (e.g., Parsons 1992, Zang et al. 1988, Hong-bang et al. 2007, Muniappan et al. 2009, PIER 2011) but, in our case, simple manual eradication would be recommended, together with a limitation of the cultivation of the plant.

To help identification in Italy, A. adenophora may be easily inserted in the keys provided by Pignatti (1982) for Italian flora, as this author keys out morphologically related (not-natural) groups. Ageratina (for the species of our interest) may be inserted in the so-called V group ("plants with opposite leaves"). This genus, being the only one belonging to Eupatoriae, is the most closely related to Ageratina in native European flora. However, considering the Italian species, the two genera can be readily distinguished. Genus Eupatorium is represented only by E. cannabinum L. s.l. a well known and common species widely distributed in all Italian regions with the typical subspecies, and in Basilicata and Sardinia with the subsp. corsicum (Loisel.) P. Fourn. (Conti et al. 2005) (this latter also reported in France and Corsica - Greuter 2009-2011). As far as A. ligustri$n a$ is concerned, its only original record for Italy is by Puccini (1950, sub Eupatorium micranthum Less.). S. Peccenini (pers. com.) communicated that the plant probably still occurs in old gardens of Liguria, but exsiccata are lacking and cultivation is now declining. Therefore, its expansion in Italy is limited. These three species are readily distinguished on account of several characters, listed in Table 2.

Table 2: Diagnostic comparison between the Eupatoriae taxa reported for Italy.

Tabela 2: Primerjava značilnosti med vrstami Eupatoriae iz Italije.

\begin{tabular}{llll}
\hline & Eupatorium cannabinum & Ageratina adenophora & Ageratina ligustrina \\
\hline $\begin{array}{l}\text { Habitus } \\
\text { Leaf shape }\end{array}$ & Perennial herb & Shrub (woody above) & $\begin{array}{l}\text { Shrub (woody above) } \\
\text { Entire, elliptic to ovate- } \\
\text { lanceolate }\end{array}$ \\
& $\begin{array}{l}\text { 3-5 Palmatisect (rarely entire), } \\
\text { with usually lanceolate }\end{array}$ & Entire lancelate to deltate & \\
Leaf margin & Coarsely serrate & Serrate & Sub-entire or slightly toothed \\
Leaf glands & Not present & Present & Present \\
Leaf upper surface & Dull & Bright & Bright \\
Leaf venation & Pinnated, with only the midrib & Main veins basal, rather & Pinnate, with only the midrib \\
& prominent in each segment & prominent beneath & prominent beneath \\
Base of the style & Pubescent & Glabrous & Glabrous \\
Flowers color & Usually pinkish & Usually white & White \\
Flowering season & Late spring-summer & Late spring-summer & Late autumn-winter
\end{tabular}




\section{ACKNOWLEDGEMENTS}

Thanks are due to Directors and Curators of NAP and FI. I am also grateful to Dr. J. Pruski (Missouri Botanical Garden) for help in identification and to Dr. D. Iamonico (Rome), Dr. L. Peruzzi (Pisa, Italy), Prof. S. Peccenini (Genoa, Italy), Dr. G. Brundu (Sassari, Italy) and prof. P. Caputo (Naples) for their helpful suggestions.

\section{REFERENCES}

Alberti, M. 2012: Notulae alla flora esotica d'Italia: 6 (148). Informatore Botanico Italiano 44: 401.

Andaloro, F., Blasi, C., Capula, M., Cele"+stiGrapow, L., Frattaroli, A., Genovesi, P. \& Zerunian, S. (eds.) 2009: L'impatto delle specie aliene sugli ecosistemi: proposte di gestione. Ministro dell'Ambiente, della Tutela del Territorio e della Tutela del Territorio e del Mare, Roma.

Barreto, R.W. \& Evans, H.C. 1988: Taxonomy of a fungus introduced into Hawaii for biological control of Ageratina riparia (Eupatorieae; Compositae), with observations on related weed pathogens. Trans. Brit. Mycol. Soc. 91(1): 81-79.

Bonpland, A.J.A., Humboldt, F.W. H.A. von. \& Kunth, C.S. 1818: Nova genera et species plantarum quas in peregrinatione ad plagam aequinoctialem orbis novi collegerunt, 4 (in folio): 96 and plate 346. Ex typographia d'Hautel, Lutetiae Parisiorum.

Brundu, G. 2008: La legislazione italiana in materia di specie vegetali alloctone. In: Galasso, G., Chiozzi, G., Azuma, M. \& Banfi, E. (eds.): Le specie alloctone in Italia: censimenti, invasività e piani di azione. Milano, 27-28 novembre 2008. Mem. Soc. Ital. Sci. Nat. Mus. Civico Storia Milano 36(1): 44.

Caputo, G., La Valva, V., Nazzaro, R. \& Ricciardi, M. 1994: La flora della Penisola Sorrentina (Campania). Delpinoa, n. s. 31-32 (1989-1990): 3-97.

Celesti-Grapow, L., Pretto, F., Carli, E., Blasi, C. (eds.) 2010: Flora vascolare alloctona e invasiva delle regioni d'Italia. Ministero dell'Ambiente e della Tutela del Territorio e del Mare, Roma.

Chen, Y.L., Kawahara, T. \& Hind, D.J.N. 2011: Eupatorieae. in: Wu, Z.Y., Raven, P.H. \& Hong, D.Y. (eds.): Flora of China, 20-21 (Astera- ceae). Science Press \& Missouri Botanical Garden Press, Beijing \& St. Louis, pp. 879-880.

Conti, F., Abbate, G., Alessandrini, A., Blasi, C. (eds.) 2005: An annotated Checklist of the Italian Vascular Flora. Palombi Editori, Roma.

Fuller, T.C. 1981: Introduction and spread of Eupatorium adenophorum in California. Proceedings of the Eighth Asian-Pacific Weed Science Society Conference, held in Bangalore: 277-280.

Galasso, G. 2012: Notulae redazionali 102-140. In: Galasso, G. \& Banfi, E. (eds.). Notulae ad plantas advenas longobardiae spectantes: 2 (29-140). Pag. Bot. 35 [2011]: 83-93.

Greuter, W. 2006-2009: Compositae (pro parte majore). In: Greuter, W. \& Raab-Straube, E. von (eds.): Compositae. Euro+Med Plantbase - the information resource for Euro-Mediterranean plant diversity. http://ww2.bgbm.org/ EuroPlusMed/[30 Oct 2012].

Heystek, F., Wood, A.R., Neser, S. \& Kistensamy, Y. 2011: Biological control of two Ageratina species (Asteraceae: Eupatorieae) in South Africa. African Entomology 19(2): 208-216.

Hong-bang, N., Liu, Wan-xue, L., Fang-hao, W., Bo, L. 2007: An invasive aster (Ageratina adenophora) invades and dominates forest understories in China: altered soil microbial communities facilitate the invader and inhibit natives. Plant and soil 294: 73-85.

Iamonico, D. 2011: Dysphania anthelmintica (Amaranthaceae), new to the non-native flora of Italy, and taxonomic considerations on the related species. Hacquetia 10(1): 41-48.

Iberite, M., Iamonico, D., Abati, S., Abbate, G. 2011: Lemna valdiviana Phil. (Araceae) as a potential invasive species in Italy and Europe: taxonomic study and first observations on its ecology and distribution. Plant Biosystems 145(4): 751-757.

King, R.M. \& Robinson, H. 1970: Studies in the Eupatoriae (Compositae). XIX. New combinations in Ageratina. Phytologia 19(4): 208-229.

King, R.M. \& Robinson, H. 1978. Studies in the Eupatorieae (Asteraceae). CLXVIII. Additions to the genus Ageratina. Phytologia 38: 323-355.

King, R.M. \& Robinson, H. 1987: The genera of the Eupatorieae (Asteraceae). Monographs in Systematic Botany from the Missouri Botanical Garden, 22. Missouri Botanical Garden, St. Louis.

Kluge, R.L. 1991: Biological control of Crofton 
weed, Ageratina adenophora (Asteraceae), in South Africa. Agriculture, Ecosystems \& Environment 37: 187-191.

Lacaita, C. (1921) Catalogo delle piante vascolari dell'ex-Principato Citra. Bull. Orto Bot. Regia Univ. Napoli 6: 101-256.

McNeill, J., Barrie, F.R., Buck, W.R., Demoulin, V., Greuter, D.L., Hawksworth, D.L., Herendeen, P.S., Knapp, S., Marhold, K., Prado, J., Proud'Homme van Reine, W.F., Smith, J.F. \& Wiersema, J.H. (eds.). 2012: International Code of Nomenclature for algae, fungi and plants (Melbourne Code): Adopted by the Eighteenth International Botanical Congress, Melbourne, Australia, July 2011. Regnum Vegetabile 154.

Michaux, A. 1803: Flora boreali-americana sistens caracteres plantarum quas in America septentrionali collegit et detexit Andreas Michaux, 2. Typis Caroli Crapelet, Parisiis \& Argentorati, p. 98.

Muniappan, R., Raman, A., Reddy, G.V.P. 2009: Biological control of the Crofton weed, Ageratina adenophora. In: Muniappan, R., Reddy, G.V.P. \& Raman, A. (eds.): Biological control of tropical weeds using arthropods. Cambridge (UK), pp. 63-73.

Nesom G. L., 2006: Ageratina. In: Flora of North America Editorial Committee (eds.), Flora of North America, 21. Oxford University Press, New York-Oxford, pp. 547-553.

Parsons, W.T. 1992: Noxious weeds of Australia. Inkata Press, Melbourne, pp. 239-242.

PIER (US Forest Service, Pacific Island Ecosystems at Risk). 2011: Ageratina adenophora. http://www.hear.org/pier/[31 Oct 2012].

Pignatti, S. 1982: Flora d'Italia, 3. Edagricole, Bologna, p. 14.

PlantNET. 2012: The Plant Information Network System of The Royal Botanic Gardens and Domain Trust, Sydney, Australia. http://plantnet.rbgsyd.nsw.gov.au [10 Dec 2012]

Pyšek, P., Richardson, D.M., Rejemánek, M., Webster, G.L., Williamson, M. \& Kischner, J. 2004: Alien plants in checklist and floras: towards better communication between taxonomist and ecologist. Taxon 53 (1): 131-143.

Puccini, G. 1950: Naturalizzazione e riproduzione spontanea di piante ornamentali nella $\mathrm{Li}$ guria occidentale. Nuovo Giorn. Bot. Ital., n. s., 52: 23-33.

Robinson, H.E., Schilling E. \& Panero, J.L. 2009. Eupatorieae. In: Funk V.A., Susanna A., Stuessy
T.F. \& Bayer, R.J. (eds.): Systematics, Evolution, and Biogeography of Compositae. I.A.P.T., Wien, pp. 731-744.

Sharma, K.C. \& Chhetri, G.K.K. 1977: Reports on studies on the biological control of Eupatorium adenophorum. Nepalese Journal of Agriculture 12: 135-157.

SEINet. 2012: Southwest Environmental Information Network. http//:swbiodiversity.org/ seinet/index.php. [06 Nov 2012].

Spach, E. 1841: Histoire Naturelle des Végétaux, 10. Librairie Encyclopédique De Roret, Paris, p. 286.

Sprengel, C. 1826: Systema Vegetabilium, 3 (XVI ed.). Sumtibus Librariae Dieterichianae, Gottingae, p. 420.

Stinca, A., D’Auria, G. \& Motti, R. 2012: Integrazioni alla flora vascolare aliena della Campania (Sud Italia). Informatore Botanico Italiano 44: 287-293.

Thiers, B. 2011: Index Herbariorum: A global directory of public herbaria and associated staff. New York Botanical Garden's Virtual Herbarium. Available from http://sweetgum.nybg. org/ih/ [accessed: 30 Oct 2012].

Tutin, T.G. 1976: Eupatorium. In: Tutin, T.G., Burges, N.A., Chater, A.O., Edmondson, J.R., Heywood, V.H., Moore, T.M., Valentine, D.H., Walters, S.M. \& Webb, D.A. (eds.): Flora Europaea, 3. Cambridge (UK): Cambridge University Press, p. 109.

USDA, 2012: ARS, National Genetic Resources Program. Germplasm Resources Information Network - (GRIN). National Germplasm Resources Laboratory, Beltsville, Maryland. http://www.ars-grin.gov/cgi-bin/npgs/html/ taxon.pl?316409 [30 Oct 2012].

Villa, M., Galasso, G. \& Banfi, E. 2012: Notulae alla flora esotica d'Italia: 6 (145). Informatore Botanico Italiano 44: 401.

Wang, R. \& Wang, Y.-Z. 2006: Invasion dynamics and potential spread of the invasive alien plant species Ageratina adenophora (Asteraceae) in China. Diversity and Distributions 12: 397-408.

Zhang, Z., Wei, Y. \& He, D. 1988: Biology of a gall fly, Procecidochares utilits (Dip.: Tephritidae) and its impact on Crofton weed, Eupatorium adenophorum. Chinese Journal of Biological Control 4: 10-13.

Received 9.1.2013

Revision received 15.4.2013

Accepted 18.4.2013 